\title{
NATURAL-HAZARD MAPS FOR LAND-USE PLANNING IN NORWAY
}

\author{
By E. Hestnes and K. Lied \\ (Norges Geotekniske Institutt, P.O. Boks 40, Tåsen, Oslo 8, Norway)
} ABstract. Problems concerning natural-hazard mapping have been discussed by the Norges
Geotekniske Institutt in pilot projects sponsored by the National Fund for Natural Disaster Assistance.
Hazard-registration maps, geomorphic hazard maps and hazard-zoning maps are defined. Hazard-zoning
maps are preferable in land-use planning. Both survey maps ( $1: 50$ ooo) and detailed maps $(\mathrm{I}: 5$ ooo $)$ are of
interest. A survey map $\left(c .600 \mathrm{~km}^{2}\right)$ would be mainly based on airphoto interpretation and could be prepared
in about I 50 h. Detailed mapping is more time consuming and should be limited to development areas.
Mapping of "marine deposits" and "other areas" are handled by separate groups, mainly because of
differences in technical and professional problems. This gives rise to two parallel series of survey maps and
detailed maps.

The proposed programmes for survey mapping states that $80 \%$ of the marine areas should be evaluated in 5 years (1980-84), and that one-third of the country should be examined for rockfalls, rock slides, and snow avalanches in Io years. Other hazard types are impossible to identify by survey mapping. There is a rising demand for detailed maps but as yet there has been no research project to standardize methods.

The hazard maps are intended primarily to be an aid in land-use planning.

RÉsumé. Cartes de risques naturels pour les plans d'occupation des sols en Norvège. Les problèmes concernant le zonage des risques naturels ont été discutés par le Norges Geotekniske Institutt dans des projets pilotes confiés au Fond National pour l'assistance dans les désastres naturels. On a défini les cartes d'enregistrement des accidents, les cartes de risques géomorphologiques et les cartes de zonage des risques. Les cartes de zonage des risques sont préférables en matière de plan d'occupation des sols. Sont nécessaires, d'une part les cartes d'ensemble ( $1: 50$ ooo) et d'autre part les cartes de détail ( $1: 5$ ooo). Une carte d'ensemble (c. 600 $\mathrm{km}^{2}$ ) est surtout basée sur l'interprétation de photo aérienne et peut être réalisée en environ i 50 heures. Les cartes détaillées demandent plus de temps et devraient être limitées aux zones en cours de développement.

Les cartographies des "dépôts marins" et des "autres zones" sont prises en main par des équipes séparées, surtout en raison des différences dans les problèmes techniques et professionnels. Elles donnent lieu à deux
séries séparées de cartes d'ensemble et de cartes de détail.

Le programme proposé pour la carte d'ensemble fixe un délai de cinq ans (1980-84) pour la réalisation de $80 \%$ des zones marines et de dix ans pour l'examen d'un tiers du pays en ce qui concerne les chutes de rochers, les glissements de terrain et les avalanches de neige. Les autres types de risques sont impossibles a identifier par des cartes d'ensemble. Il y a une demande croissante pour des cartes de détail mais il n'y a pas
encore eu de projet de recherche pour en fixer la méthodologie.

Le but principal des cartes de risques est d'aider à la planification de l'utilisation des sols.

Zusammenfassung. Karten der natürlichen Gefährdung für die Landnutzungsplanung in Norwegen. Vom Norges Geotekniske Institutt wurden in Grundsatzstudien, gefördert durch den Nationalfonds für die Hilfe bei Naturkatastrophen, die Probleme einer Kartierung der Naturgefahren untersucht. Es werden Karten der Gefahrenaufzeichnung, der geländegegebenen Gefährdung und der Gefahrenzonung unterschieden. Letztere verdienen den Vorzug bei der Landnutzungsplanung, wobei sowohl Übersichtskarten I : 50 ooo wie Grundkarten I : 5 ooo von Interesse sind. Eine Übersichtskarte $\left(c\right.$. $\left.600 \mathrm{~km}^{2}\right)$ würde hauptsächlich auf Luftbildinterpretation beruhen und könnte in etwa 150 Stunden bearbeitet werden. Grundkarten erfordern
mehr Zeitaufwand; sie sollten auf Entwicklungsgebiete beschränkt bleiben.

Die Kartierung von "Meeresablagerungen" und "anderen Gebieten" wird von selbständigen Gruppen vorgenommen, vor allem wegen der damit verbundenen, verschiedenen technischen und beruflichen
Probleme. Die Folge ist die Entwicklung zweier Parallelserien von Übersichts- und Grundkarten.

Das vorgeschlagene Programm für Übersichtskarten sieht vor, dass $80 \%$ der Küstengebiete in 5 Jahren (1980-84) bearbeitet werden sollten und dass ein Drittel des Landes auf Felsstürze, Felsrutsche und Schneelawinen in 1o Jahren untersucht werden sollte. Andere Gefährdungsarten können in Übersichtskarten nicht dargestellt werden. Der Bedarf an Grundkarten steigt ständig, doch gibt es bisher kein Forschungsprojekt
zur Vereinheitlichung der Methoden.

Die Gefährdungskarten sollen in erster Linie eine Hilfe für die Landnutzungsplanung sein.

\section{Introduction}

Narrow valleys and steep mountain slopes and cliffs are common topography in Norway, and landslides and avalanches are relatively common phenomena especially in the fjord and valley districts in western and northern Norway (Fig. I). During the last decade it has become common practice to plan housing in concentrated building areas. At the same time these areas have been increased towards the valley sides, due to the desire to preserve arable land. As a result, housing is subjected to an increasing slide and avalanche risk. 
Not only the mountainous parts of Norway exhibit slide danger to housing. On the flat lowland areas of eastern Norway and Trøndelag, quick-clay slides may occur in marine deposits, which are located up to $220 \mathrm{~m}$ above sea-level due to the isostatic uplift after the ice age (Fig. I).

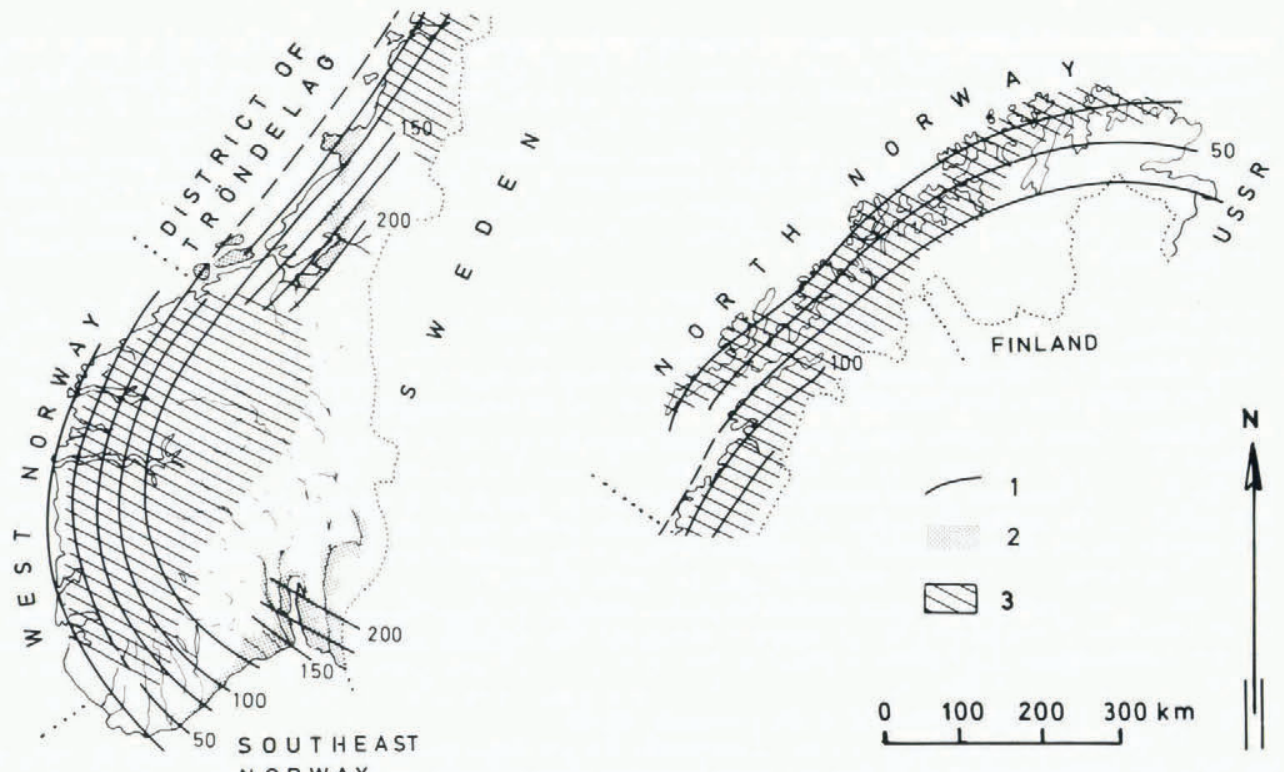

Fig. I. Main areas of Norway exposed to natural hazards. (I) Isobases showing heights of the marine limit ( $m$ a.s.l.). (2) Main areas of marine deposits. (3) Fjord and valley districts.

The Norwegian National Building Code states: "Ground can only be built on if there is sufficient safety against subsidence, inundation, landslides, etc." This implies that areas which are not obviously safe should be regarded as insecure until an evaluation of natural hazards has been accomplished. This again makes zoning necessary.

In Norway the governmental organization, National Fund for Natural Disaster Assistance (NFNDA) is responsible for damage compensation and safety structures against natural hazards. This organization has been active in preventing development in areas which could be subjected to damage. The Norges Geotekniske Institutt (NGI) has been engaged by NFNDA to accomplish three pilot projects on natural hazard mapping.

The first project had a general character with three main purposes (Hestnes, unpublished [a]): (I) Elucidate problems connected with registration and mapping of terrain exposed to natural hazards. (2) Evaluate methods to define risk degree and boundaries for different types of hazard areas. (3) Suggest methods of natural-hazard zonation in Norway.

The second and third projects involve: zonation of dangerous marine deposits (Løken, unpublished [a], [b]) and zonation of areas subjected to other hazard types (Hestnes, unpublished [b]). The main purposes of these projects are: (I) Evaluation of professional and practical problems connected with the production of hazard-zoning maps, scale $1: 50$ ooo.

(2) Preparation of a schedule for future production of such maps.

An approach to these problems and the practical solutions are presented in this paper. 


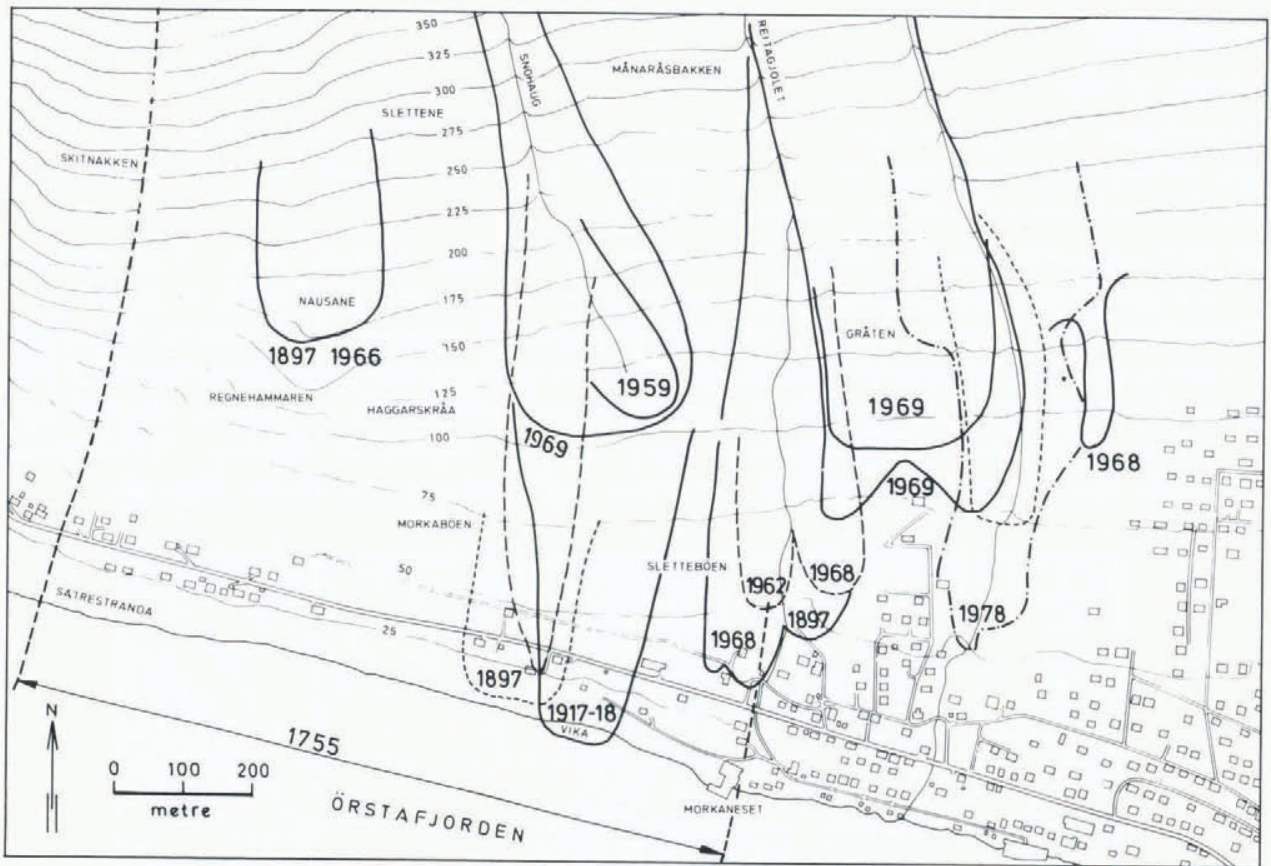

Fig. 2. A section of a hazard-registration map (snow avalanches). The original map is at a scale of $1: 5$ ooo with a contour interval of $5 \mathrm{~m}$.

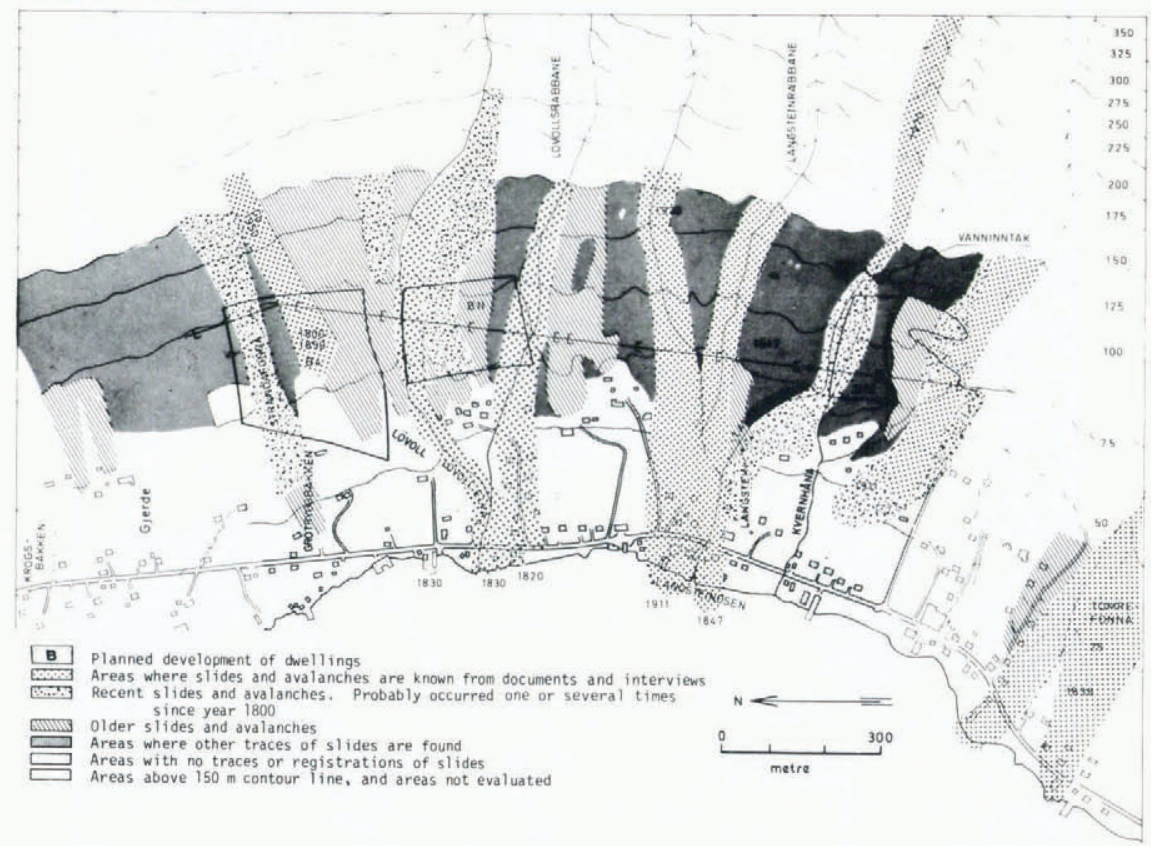

Fig. 3. A section of a geomorphic hazard map. The original map is at a scale of $1: 5$ ooo with a contour interval of $5 \mathrm{~m}$ (Larsen, unpublished). 


\section{Definitions}

\subsection{Types of maps}

Depending on map content and methods used in data collection and data processing, the Norges Geotekniske Institutt found it appropriate to distinguish between three types of natural-hazard maps (Hestnes, unpublished [a]):

Hazard-registration maps. Maps containing historically known slides and avalanches, compiled from literature and documents, interviews and field work (Fig. 2).

Geomorphic hazard maps. Maps including historically known slides and avalanches, and areas exposed to natural hazards identified by geomorphological investigations (Fig. 3).

Hazard-zoning maps. Maps which show potential risk areas, compiled on the basis of geomorphological investigations and known historical events. Mathematicalstatistical methods are applied to predict potential run-out zones (Fig. 4).

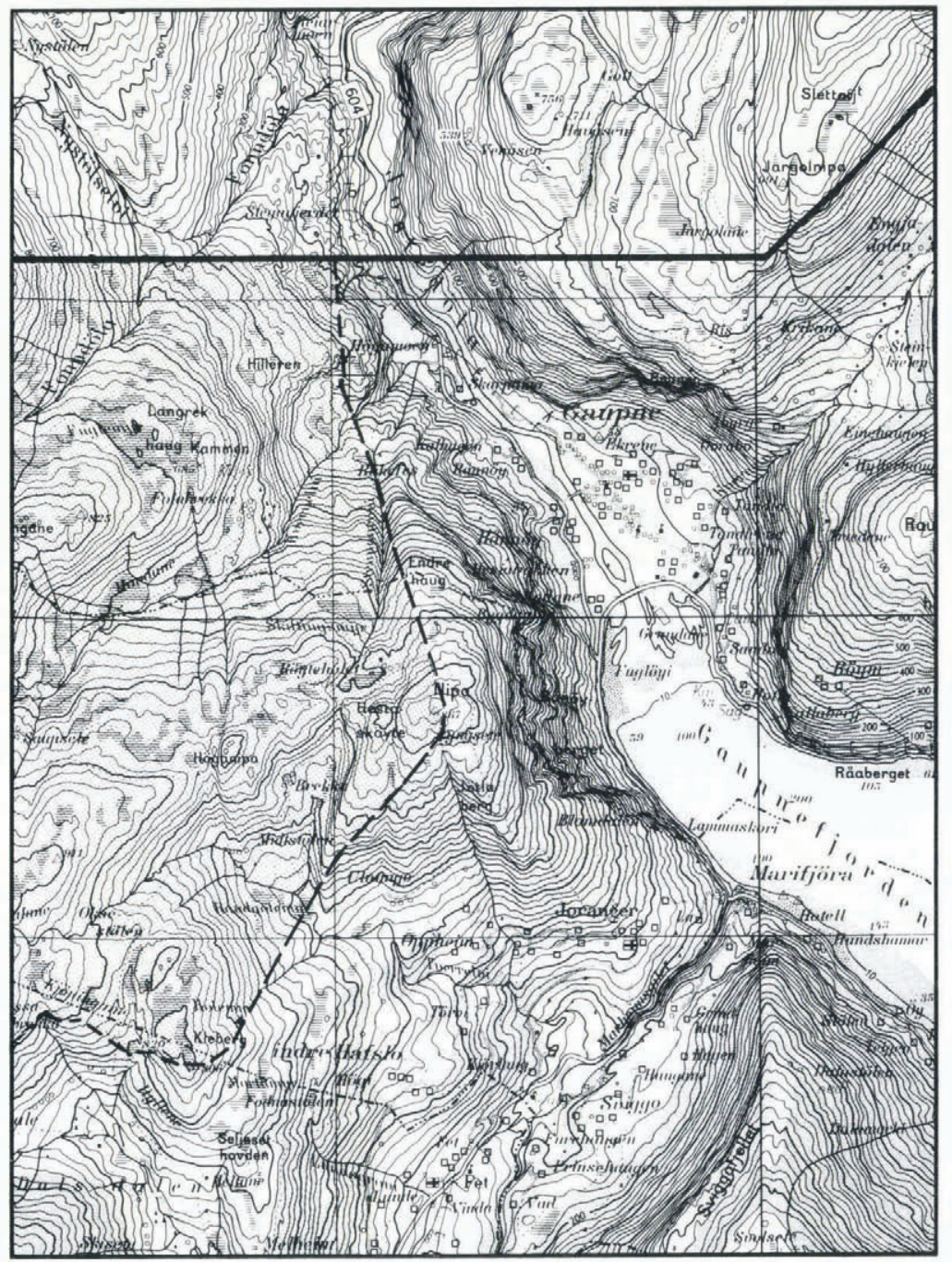

Fig. 4. A section of a hazard-zoning map; the original is at a scale of $1: 50$ ooo and in three colours. For the legend see Figure 8. (Printed by permission of the Norwegian Geographical Survey.) 


\subsection{Mapping standard}

It is appropriate to distinguish between detailed maps and survey maps (Hestnes, unpublished $[\mathrm{a}],[\mathrm{b}])$.

Detailed maps should have a high degree of accuracy. These maps demand comprehensive field work and they are time-consuming to produce. They are based on the Norwegian economic map series at a scale of $1: 5000$ (Figs 2 and 3). In certain cases other scales may be used, for instance I : 1000 .

Survey maps are meant to give general information of hazard risks and will cover a fairly large area in a short time and at a low production cost. It is estimated that each map sheet at a scale of I : 50000 , which covers an area of $c$. $600 \mathrm{~km}^{2}$, should be evaluated in 4 weeks ( 50 h) (Fig. 4). The basic maps for this work are the national topographic map series (Series M7 I I), compiled by the Norwegian Geographical Survey.

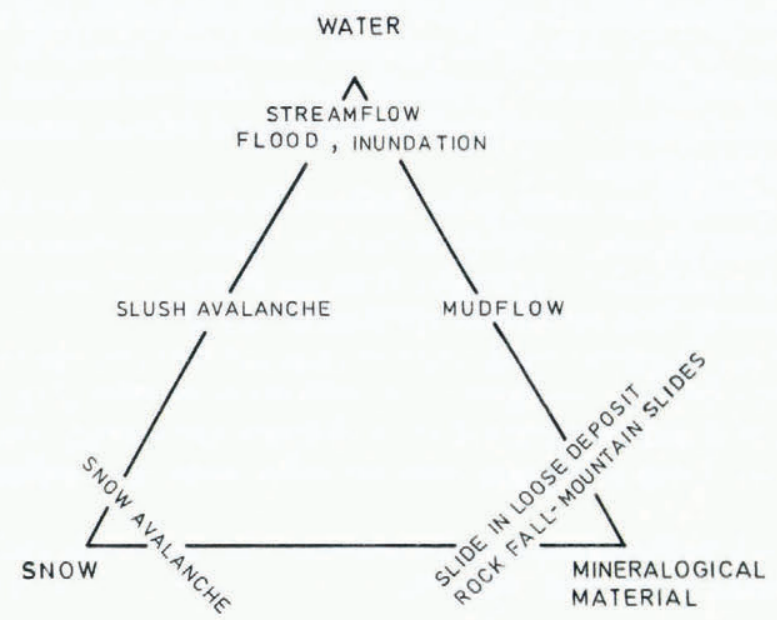

Fig. 5. Classification of natural hazards (modified after Nobles (1966)).

\subsection{The different hazard types}

In Figure 5 natural hazards are classificated in main types based on their material content. However, in nature, one may find all kinds of transitional forms between the different hazard types. Slides and avalanches may also generate waves if they terminate in lakes or fjords and powerful air waves may be created by major snow avalanches and mountain slides.

The types of natural hazard which should be taken into account in the planning of housing areas are:

Snow avalanches, slush avalanches.

Rockfalls $\left(<\mathrm{roO} \mathrm{m}^{3}\right)$, rock slides, mountain slides $\left(>10000 \mathrm{~m}^{3}\right)$.

Slides in loose deposits: clay slides, submarine slides, slides in other loose deposits.

Mudflows, inundations.

Waves generated in air by avalanches and slides.

Waves generated in water by avalanches and slides.

This classification is used by the Norges Geotekniske Institutt (Hestnes, r979[a], [c]). 


\section{Selection of map type, map content and mapping standard}

Hazard-zoning maps are the only type of hazard maps that include an estimate of potential risk areas. This means: predicts future natural-hazard activity and damage. The other maps mentioned in Section 2.I, hazard-registration maps and geomorphic hazard maps, give less information of the potential slide danger.

Hazard-zoning maps, which include as many hazard types as possible, have the greatest value. For planning and development, both detailed maps and survey maps may be useful.

\section{Discussion}

\subsection{Principal problems concerning hazard-zoning maps}

Optimally, boundary lines between areas of different risk levels should be drawn on hazard-zoning maps. Ideally, these boundaries should be based on mathematical and statistical methods in which all relevant field parameters are taken into account. The definitions of the hazard zones could then be based on what risk level the community is willing to accept. However, their nature is difficult to quantify, and exact criteria for rupture conditions, run-out distances, and so forth, are not available for the different hazard types. The hazardzoning maps are therefore based on mathematical-statistical models, combined with empirical and geomorphological knowledge.

The hazard types defined are more or less difficult to evaluate. Rockfalls, rock slides, and mountain slides, for instance, may occur whenever the angle of a mountain slope exceeds the angle of friction, which is difficult to quantify. Run-out distance of mountain slides also seems to increase with increasing slide volumes (Scheidegger, 1975).

Slush avalanches may in certain cases start moving almost everywhere on sloping terrain. Consequently, risk areas for slush avalanches are difficult to identify (Fig. 6). A third hazard type which is difficult to identify is debris slides of different consistency, ranging from moraine material to block talus. Only in certain cases do older slides give information about these hazard types.

Concerning quick-clay slides, it is usually necessary to perform sounding, sampling, and laboratory tests to evaluate the slide risk. Such investigations are always costly and timeconsuming.

The possibility of mapping areas subject to inundation depends upon the existing information on topography and of river discharge.

Maximum wave heights generated by avalanches and slides are to a certain degree possible to calculate. On the other hand, it is almost impossible to predict the probability of mountain slides, and consequently there is little possibility of taking into account the risk and consequences of potential mountain slides in hazard zoning.

The above-mentioned aspects indicate the limitations in the value and usefulness of the hazard-zoning maps. However, the advantage of hazard-zoning maps is obviously higher than of registration maps and geomorphic maps, which only include incidents that have occurred.

Hazard maps should comprise a description of the limitations of the maps, what kinds of natural hazards are treated, and the accuracy of the zone boundaries (Hestnes, unpublished [b]).

\subsection{Discussion of risk level}

In land-use planning it would be unrealistic to guarantee $100 \%$ safety against avalanches and slides. Especially in the narrow valleys and fjord districts of western and northern Norway, such an aim would be too costly, because housing would then have to be kept far away from all kinds of slopes, and most of the arable land would have to be occupied by 


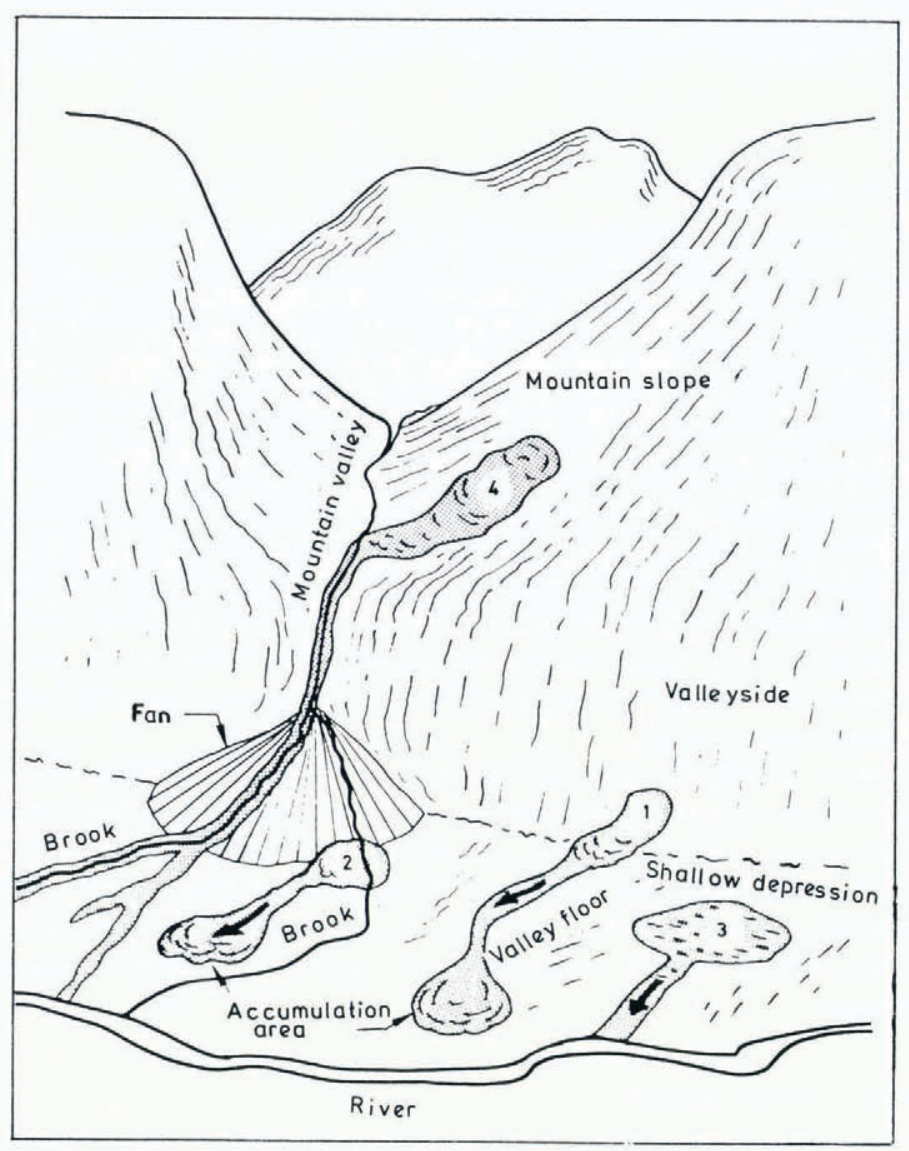

Fig. 6. Starting zones of slush avalanches.

buildings. All activities include some risk, and some risk from natural hazards also have to be accepted.

How safe housing areas should be is a political question, and the authorities have to decide the risk level which should be accepted. The role of the experts on natural hazards is limited to quantifying the degree of danger (Lied, I979). It is important that both the authorities and the experts respect this.

Acceptable risk level for housing areas should be evaluated by comparison with other types of social risk. The average probability of being killed by natural hazards in Norway is about $3 \times 10^{-6}$ per year. Fatal risk in fires is about $1.25 \times 10^{-5}$ and the average risk for all kinds of fatal accidents is $5 \times 10^{-4}$ (Jenssen and Sande, 1973).

Based on accident statistics, Starr ( 1969 ) has proposed a general international standard of acceptable annual risk level of about $\mathrm{I} \times \mathrm{IO}^{-6}$ concerning "planned activities". (Death risk per hour is less or equal to $\mathrm{I} \times \mathrm{IO}^{-10}$.) The proposed highest tolerable risk level for dwelling houses in Norway is $3 \times 10^{-3}$ per year (Lyng, 1979). Our accident statistics show that five to ten houses are destroyed for every person killed in a house by snow avalanches. This corresponds to a personal death risk of $6 \times 10^{-4}$ to $3 \times 10^{-4}$ per year. The difference between this risk level and $\mathrm{I} \times \mathrm{IO}^{-6}$ proposed by Starr for "planned activities" is considerable. 
However, in certain districts of Norway it would be impossible to find suitable development areas which satisfy that high degree of safety which corresponds to the "I ooo ooo year" avalanche.

\section{Current zoning situation}

For many years, different types of hazard mapping and registration have been carried out, especially for snow avalanches and quick-clay slides (Ramsli, I953, unpublished; Bjerrum, I971; Hestnes, r979[b]; Haug, unpublished; Hutchinson and Jørstad, unpublished; Lied, unpublished; Rye, unpublished).

About $\mathrm{I}$ ooo snow-avalanche paths are recorded in detail on maps at scales of $\mathrm{I}: 50000$ and I : 5000 , and about 2000 on older topographic maps. All the avalanches are recorded to their known maximum extent. To some degree, other types of landslides are recorded in connection with certain projects. Traditionally, slides in marine deposits have been handled and mapped separately mainly because of professional and practical reasons (Fig. I). This is also the case today, because the mapping of quick-clay hazards and other hazard types is treated by two independent project groups at NGI. A composite hazard-zoning map should be compiled where all hazard types appear within the same map sheet. In relation to other countries which experience natural-hazard problems, systematic mapping in Norway has been carried out to a small extent only.

I 424 people were killed by natural hazards in Norway during the roo-year period 1871-1970. $55 \%$ of these lost their lives because of snow avalanches, slush avalanches, and air waves generated by snow avalanches. 175 people (12\%) perished in waves generated by the mountain slides at Loen in 1905 and 1936 , and Tafjord in I934 (Jørstad, I968). In the quickclay slide at Verdalen in I893, I I 2 people (8\%) lost their lives. These statistics demonstrate that snow and slush avalanches are responsible for most of the death's caused by avalanches and slides in Norway.

\subsection{Survey mapping of marine deposits}

Methods of recording areas subject to quick-clay hazards were prepared in the period 1967-71 (Bjerrum, I97I). The quick-clay slide at Rissa, Trøndelag, on 29 April 1978 emphasized the problems connected with such slides (Fig. 7).

A pilot project is planned to start in $1979-80$. This will further elucidate the professional and practical problems connected with survey mapping (scale I : 50 000), and establish criteria and guidelines for the future survey mapping (Løken, unpublished [a], [b]). The evaluation methods will mainly be based on: (I) Quaternary maps covering marine-clay deposits, (2) geomorphological interpretation of vertical air photographs at a scale of I : 20000 (infra-red photographs), (3) field investigations and (4) simple core drilling and soil testing.

The plan is to divide the marine-clay areas in two main groups:

Areas where development may be carried out without further investigations. Areas where light buildings may be constructed and where smaller fills and excavations can take place without geotechnical investigations. Quick-clay deposits may be present, but the topography is such that quick-clay slides will probably not occur.

Areas where investigations should be carried out before development starts. Areas where the topography implies that the collapse of ground may trigger quick-clay slides.

Directions for use that explain aim of map, content, and limitations, will also be discussed. Defining the exact boundary between safe and dangerous areas has to be undertaken by detailed mapping. 


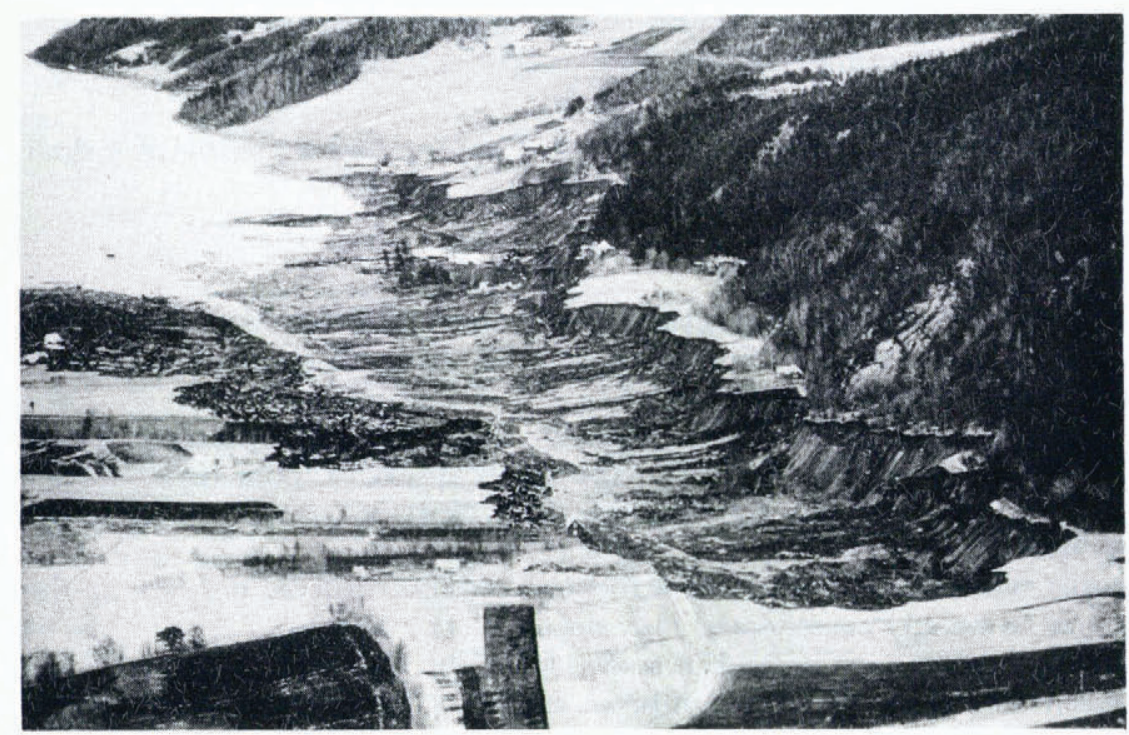

Fig. 7. Quick-clay slide at Rissa, Trondelag, 29 April 1978. 33 ha of cultivated land disappeared. Length of slide I $500 \mathrm{~m}$. Seven farms and five dwellings were damaged or completely destroyed. Only one person was killed. (Photograph by Aftenposten, 1978.)

\subsection{Survey mapping of other hazard types}

A method of mapping hazard types exclusive of slides in marine deposits was worked out by the NGI in 1978 (Hestnes, unpublished [b]). Experience from this project showed that if a survey map were to be produced in $150 \mathrm{~h}$ of work the mapping must be based mainly on interpretation of air photographs and topographic maps (Section 2.2). Air-photograph interpretation is most conveniently done by using the instrument Interpretoshop B (Carl Zeiss, Jena, Germany (DDR)).

The main principle of the mapping is the evaluation of potential hazard zones, based on terrain gradient and topographic formations (Lied and Bakkehøi, I980; Hestnes, 1979[c], unpublished [b]). Field work and the use of historical documents should be kept to a minimum. It is underlined that this type of survey map does not give information on the real danger but of potential danger only. The exact boundaries of the hazard zones must be evaluated by detailed mapping.

It was further concluded that the only hazard types which could be identified by this type of mapping are the potential danger of rockfalls, rock slides, and snow avalanches. Other hazard types have to be defined as "not investigated". However, quite obviously risks of the other hazard types will have to be taken into account.

It is not possible to guarantee absolute safety against rockfalls, rock slides, and snow avalanches outside the hazard zone. The map scale, technical aids and time at disposal are limiting factors. Usually, cliffs and slopes lower than $\mathrm{s}$ o $\mathrm{m}$ and with a horizontal extent of less than $30-50 \mathrm{~m}$ are impossible to identify on air photographs and mark off on the maps. An uncertainty of $\pm 50 \mathrm{~m}$ must also be considered when information is transferred from the air photographs to the maps.

Based on the results from this project, it is proposed that the survey map should include the following four types of areas: 
i. Areas where developments may be undertaken without further investigations.

ii. Areas where investigations should be carried out before development starts.

iii. Areas which are supposed to be without developmental interest.

iv. Areas not evaluated.

A section of a map of this type is given in Figure 4 and a preliminary draft of user's directions is shown in Figure 8.

\subsection{Detailed mapping of marine deposits}

Sampling and soil testing are necessary to establish the location and extent of hazard zones, and the relative danger of different parts of an area. Guidelines for detailed mapping have not yet been worked out.

The geotechnical investigations in connection with detailed mapping might be done by private consultant companies or the municipal technical service. Sometimes it might be more economic to carry out stabilizing improvements directly instead of undertaking timeconsuming investigations.

Submarine slides occur because of structural collapse in loose deposits of fine sand or coarse silt, and in weakly consolidated clay deposits. The possibility of a satisfactory hazard evaluation is limited for such slides, but some idea of the potential danger may be gained by boring, acoustic profiling, the use of explosives, and investigations of mass content and porosity (Karlsrud, 1979).

\subsection{Detailed mapping of other hazard types}

At present the following routines for detailed hazard zoning are used at the NGI (Hestnes, I979[b], unpublished [a]): (I) Systematic collection of data concerning avalanche and slide frequency, and earlier run-out distances, based on interviews and documents (Fig. 2). (2) Geomorphological recording of slide and avalanche activity, deposits, tracks, and rupture conditions (Fig. 3). (3) Geomorphological investigations with the intention of predicting future avalanche and slide activity. (4) Evaluation of avalanche frequency, maximum run-out, and consequences of potential hazards based on collected material and climatic data. (5) Calculation of run-out distance based on mathematical-statistical criteria if possible.

By using these routines, it should be possible to evaluate the relative degrees of hazard between the different hazard types within an investigated area.

As long as the exact criteria for the calculation of run-out distance and frequency are not available, the calculation methods have to be supplemented by subjective judgements based on personal experience.

The main aim in detailed mapping is to establish hazard zones with a high degree of accuracy. To do this, we have to discuss how to define the degree of hazard based on a consequence analysis of the different hazard types. An intensified research programme on avalanche run-out and rupture conditions is also needed.

Detailed maps, which take account of all kinds of hazard and record accurate zones for different risk levels, will probably never be possible to construct.

\section{Future zoning programme}

The political authorities have not given any standards for tolerable risk level against natural hazards. Based on the Norwegian National Building Code, it is the local municipality boards which decide what should be accepted. However, a new national regulation is planned which specifies a highest tolerable risk level for buildings equal to $3 \times 10^{-3}$ per year (Section $4 \cdot 2)$. 


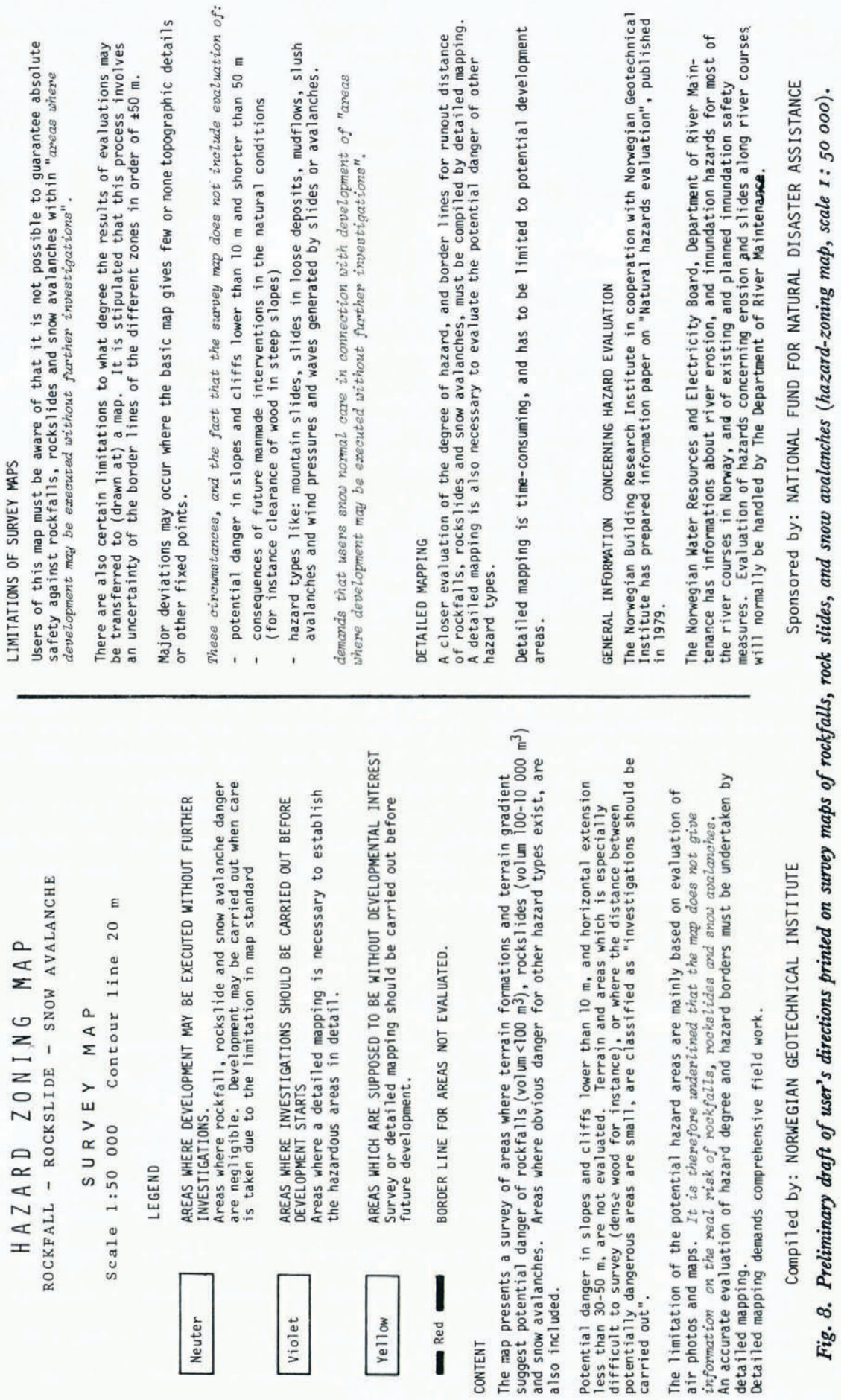


The introduction of these quantitative regulations means that a first step in hazard zonation in principle has to be based on these criteria. However, it is beyond doubt that in most cases it will be impossible to evaluate a boundary line with exactly the degree of hazard. On the other hand, most parts of an investigated area clearly will either be safer or more hazardous. The political authorities, therefore, will have a better chance of making decisions concerning the development of areas. By these standards, the same degrees of hazard will be practised for the whole country.

\subsection{Survey maps}

On the basis of the pilot projects mentioned in Section I, the National Fund for Natural Disaster Assistance, in co-operation with the Norges Geotekniske Institutt, has planned two series of survey maps. NFNDA's goal is that these series should be an aid in municipal development.

When the methods and classifications for survey mapping of marine deposits are clarified, $80 \%$ of these areas will be evaluated in 5 years ( $1980-84)$. The last $20 \%$ are spread all over the country. Rational surveying of these areas will be difficult and might require special methods (Løken, unpublished [a], [b]).

The methods for survey mapping of rockfalls, rock slides and snow avalanches have been mentioned in Section 5.2. The National Fund for Natural Disaster Assistance has requested that one-third of the country $\left(120000 \mathrm{~km}^{2}\right)$ should be mapped within ro years. The most hazardous parts of the country will have first priority.

\subsection{Detailed maps}

In the last few years there has been a rising demand for detailed hazard-zoning maps from local communities and other authorities. It is presumed that the need for such maps will increase in the future. It is also believed that the survey maps themselves will create an accelerating demand for detailed studies in connection with development.

Detailed mapping of marine deposits potentially exposed to sliding could be limited to "areas where investigations should be carried out before development starts" (Section 5.I).

The limitations of the survey maps of rockfalls, rock slides, and snow avalanches, demonstrate, however, that detailed hazard zoning in these maps requires that no areas are excluded.

\section{REFERENCES}

Bjerrum, L. 1971. Kvikkleireskred. Et studium av årsaksforhold og forbygningsmuligheter. Publikationer. Norges Geotekniske Institutt, 89 .

Haug, J. M. Unpublished. Snøskred. Registrering og kartlegging innen Sunndal kommune. [Hovedfagsoppgave, Geografisk Institutt, Universitetet i Oslo, 1974.]

Hestnes, E. 1979[a]. Hvilke skredtyper må planleggerne ta hensyn til?. (In Skredfare og arealplanlegging. Vurdering av faregrad og sikringstiltak. [Oslo], Norske Sivilingeniørers Forening [and] Norges Geotekniske Institutt, p. 1.1-1.30.)

Hestnes, E. 1979[b]. Kartlegging av skredfarlige områder i Norge. (In Skredfare og arealplanlegging. Vurdering av faregrad og sikringstiltak. [Oslo], Norske Sivilingeniørers Forening [and] Norges Geotekniske Institutt, p. $17.1-17.24 \cdot$ )

Hestnes, E. 1979[c]. Skredfarevurdering. Norges Byggforskningsinstitutt. Byggforskserien. Byggdetaljer A511.202, Del $\mathrm{I}-2$.

Hestnes, E. Unpublished [a]. Prøveprosjekt vedrørende kartlegging av skred. [Norges Geotekniske Institutt, Oslo. Oppdragsrapport 7642 I-1, 1977.]

Hestnes, E. Unpublished [b]. Prøveprosjekt vedrørende kartlegging av skred. Oversiktskartlegging M I: 50.000. [Norges Geotekniske Institutt, Oslo. Oppdragsrapport 78430-I, i979.]

Hutchinson, J. N., and Jørstad, F. Unpublished. Orienterende undersøkelser av skredfaren i Namdalen. [Norges Geotekniske Institutt, Oslo. Oppdragsrapport O.910, 1961.]

Jenssen, A., and Sande, T. 1973. Risikoanalyse. Konkretisering av fare som ledd $i$ beslutningsprosessen. Trondheim, Forsvarets Byggningstjent...e. Vassdrags- og Havnelaboratoriet. 
Jørstad, F. A. 1968. Waves generated by landslides in Norwegian fjords and lakes. Publikationer. Norges Geotekniske Institutt, 79, p. I 3-32.

Karlsrud, K. 1979. Undersjøiske utglidninger og skred. (In Skredfare og arealplanlegging. Vurdering av faregrad og sikringstiltak. [Oslo], Norske Sivilingeniorers Forening [and] Norges Geotekniske Institutt, p. 15.1-15.30.)

Larsen, J. O. Unpublished. Detaljerte undersøkelser av skredforholdene i tre nye utbyggingsområder i Tromrefjord. [Norges Geotekniske Institutt, Oslo. Oppdragsrapport 76419-2, 1977.]

Lied, K. 1979. Anvendelse av risikoanalyse i skredfarevurderingen. (In Skredfare og arealplanlegging. Vurdering av faregrad og sikringstiltak. [Oslo], Norske Sivilingeniørers Forening [and] Norges Geotekniske Institutt, p. I6. I-I6.24.)

Lied, K. Unpublished. Snøskred i Ørsta kommune. [Written in r971.]

Lied, K., and Bakkehøi, S. 1980. Empirical calculations of snow-avalanche run-out distance based on topographic parameters. Fournal of Glaciology, Vol. 26, No. 94, p. $165-77$.

Løken, T. Unpublished [a]. Vedrørende kartlegging av kvikkleireområder. [Norges Geotekniske Institutt,

Oslo. Notat 25.09.78, 1978.]
Løken, T. Unpublished [b]. Vedrorende kartlegging av områder der en kan forvente kvikkleire. [Norges Geotekniske Institutt, Oslo. Notat I6.1 1.78, 1979.]

Lyng, O. I979. Bygningsloven og byggeforskriftene. (In Skredfare og arealplanlegging. Vurdering av faregrad og sikringstiltak. [Oslo], Norske Sivilingeniørers Forening [and] Norges Geotekniske Institutt, p. 3. I-3.7.)

Nobles, L. H. I 666 . Slush avalanches in northern Greenland and the classification of rapid mass movements. Union de Géodésie et Géophysique Internationale. Association Internationale d'Hydrologie Scientifique. Commission pour la Neige et la Glace. Division Neige Saisonnaière et Avalanches. Symposium international sur les aspects scientifiques des avalanches de neige, 5-10 avril 1965, Davos, Suisse, p. 267-72. (Publication No. 69 de l'Association Internationale d'Hydrologie Scientifique.)

Ramsli, G. 1953. Litt om snøskred og snøskredkartlegging i Norge. Norsk Geografisk Tidsskrift, Bd. 14, Ht. I-4, p. $22 \mathrm{I}-28$.

Ramsli, G. Unpublished. Report on avalanche zoning in Norway with reference to other Scandinavian countries. [Written 1975.]

Rye, N. Unpublished. Rapport vedkomande skredfare i Kvinnherad. [Written 1974.]

Scheidegger, A. E. 1975. Physical aspects of natural catastrophes. Amsterdam, etc., Elsevier Scientific Publishing Co.

Starr, C. 1969. Social benefit versus technological risk; what is our society willing to pay for safety? Science, Vol. 165 , No. 3899 , p. $1232-38$. 